Natural Hazards and Earth System Sciences (2001) 1: 159-164

(C) European Geophysical Society 2001

Natural Hazards and Earth System Sciences

\title{
Radon measurements along active faults in the Langadas Basin, northern Greece
}

\author{
C. Papastefanou, M. Manolopoulou, S. Stoulos, A. Ioannidou, and E. Gerasopoulos \\ Aristotle University of Thessaloniki, Atomic and Nuclear Physics Laboratory, Thessaloniki 54006, Greece
}

Received: 6 June 2001 - Revised: 3 September 2001 - Accepted: 21 December 2001

\begin{abstract}
A network of three radon stations has been established in the Langadas Basin, northern Greece for radon monitoring by various techniques in earthquake prediction studies. Specially made devices with plastic tubes including Alpha Track-etch Detectors (ATD) were installed for registering alpha particles from radon and radon decay products exhaled from the ground, every 2 weeks, by using LR-115, type II, non-strippable Kodak films, starting from December 1996. Simultaneous measurements started using Lucas cells alpha spectrometer for instantaneous radon measurements in soil gas, before and after setting ATDs at the radon stations. Continuous monitoring of radon gas exhaling from the ground started from the middle of August 1999 by using silicon diode detectors, which simultaneously register meteorological parameters, such as rainfall, temperature and barometric pressure. The obtained data were studied together with the data of seismic events, such as the magnitude, $M_{L}$, of earthquakes that occurred at the Langadas Basin during the period of measurements, as registered by the Laboratory of Geophysics, Aristotle University of Thessaloniki, in order to find out any association between them.
\end{abstract}

\section{Introduction}

There have been various reports dealing with the measurements of radon concentration in soil gas emanating from the ground along active faults which may provide useful signals before seismic events (King, 1977, 1978, 1980; MogroCampero et al., 1980; Hauksson, 1981). Anomalous changes in subsurface radon concentrations may be expected prior to earthquakes according to the dilatancy-diffusion model for earthquake occurrence (Scholz et al., 1973).

In the Langadas basin, northern Greece, between the Lake Langadas (Lake Koronia) and the Lake Volvi (Figs. 1a and b), there is a great fault, named the Stivos fault, with a dis-

Correspondence to: C. Papastefanou

(papastefanou@physics.auth.gr) tant of about $50 \mathrm{~km}$ from the city of Thessaloniki $\left(40^{\circ} 38^{\prime} \mathrm{N}\right.$, $\left.22^{\circ} 59^{\prime} \mathrm{E}\right)$. It is a normal type fault in the Servo-Makedonian Zone (Skordilis, 1985). The background (substrate) of the Servo-Makedonian Zone has been formed from minerals of palaeozoic era or older, which have been metamorphosized during the palaeozoic or mesozoic era. In aging of the crystallic background, the results gave upper palaeozoic or lower kaenozoic. Two series might be distinguished in the crystallo-schistic of the Servo-Makedonian Zone, the lower series of Kerdylia and the upper series of Vertiskos (Figs. 1a and $\mathrm{b}$ and the Appendix 1).

At the Stivos fault, large earthquake events of $M_{L}=6.5$ occurred on 20 June 1978, of $M_{L}=5.2$ on 19 February 1984 and of $M_{L}=5.8$ on 4 May 1995. A radon monitoring station using solid-state nuclear track-etch detectors (cellulose nitrate films of type CA 80-15 Kodak) had been established at that fault in the Stivos village for the period August 1982 June 1985 (Papastefanou et al., 1989). After a decade, three different radon monitoring stations have been established at Gerakarou, No. 1, at Stivos, No. 2 and at Sholari, No. 3, in the Langadas Basin (Figs. 1a and 1b) for the period starting from December 1996 onwards.

In the Langadas Basin, at the spas of Nea Apollonia, No. 4 (Fig. 1b), $60 \mathrm{~km}$ from the city of Thessaloniki, south-east of the Lake Volvi, a radon monitoring station is registering continuously radon anomalies in the waters of spas (thermal springs). Two active hot springs, namely Loutra (spa) Langadas $\left(40^{\circ} \mathrm{C}\right)$ and Loutra of Nea Apollonia $\left(49^{\circ} \mathrm{C}\right)$, exist in the area of Langadas Basin. The hot spring action is connected to the neotectonic faulting and must be more intensive in the past than today, as indicated by the extensive distribution of travertines along the periphery of the basin and around Lake Volvi, in particular (Loutra of Nea Apollonia, Nea Apollonia, Apollonia, Nea Madytos, Megali (great) Volvi, Nymphopetra, Profitis, Fig. 1b).

The geothermal gradient in the area is high and several "warm" boreholes were drilled for agricultural purposes (greenhouses) in the vicinity of the Loutra Langadas (35$40^{\circ} \mathrm{C}$ ), max $330 \mathrm{~m}$, Loutra of Nea Apollonia $\left(55^{\circ} \mathrm{C}\right)$ and 

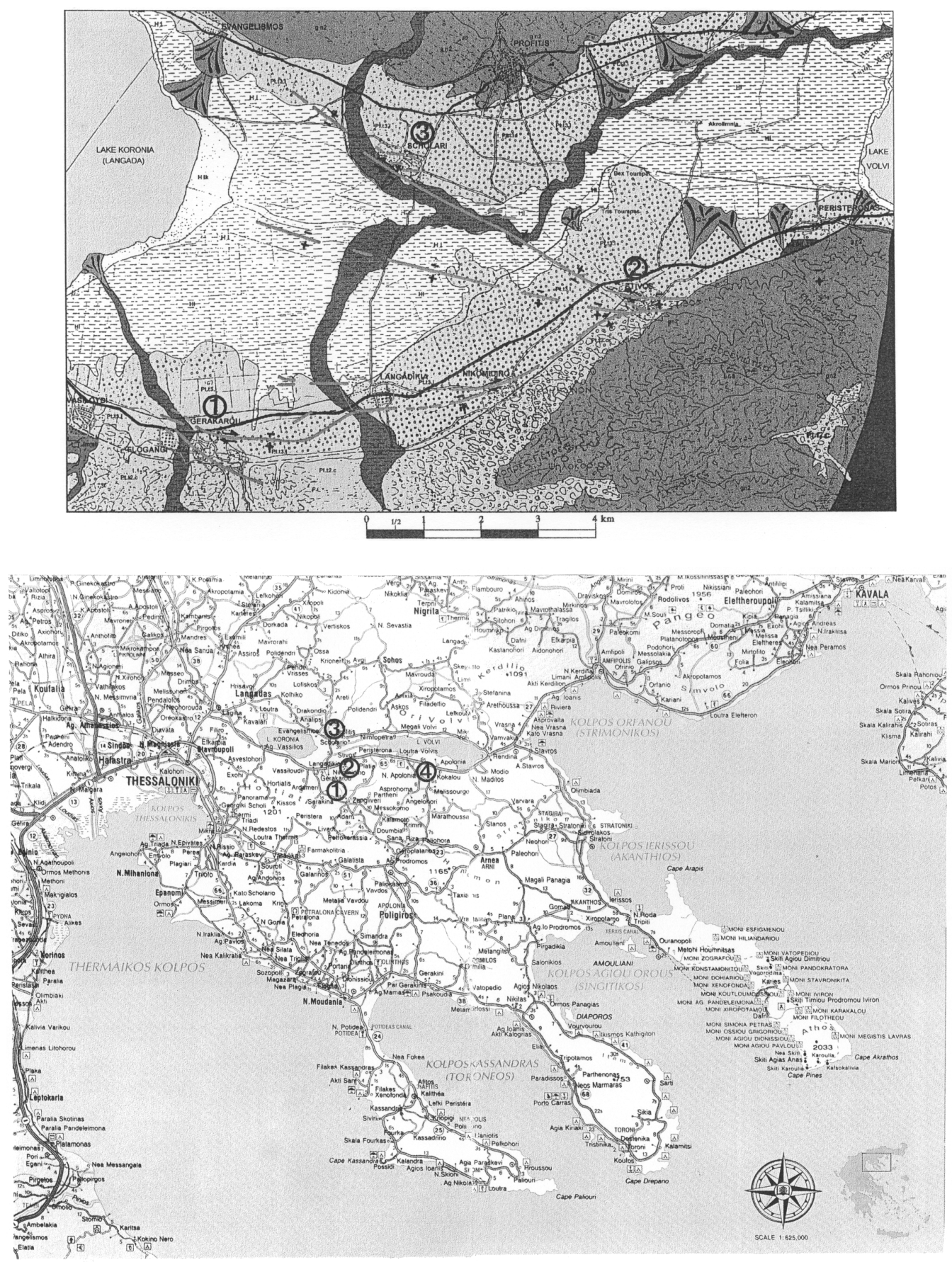

Fig. 1. (a) Geological map of Langadas Basin. (b) Geographical map of Langadas Basin.

Nymphopetra $\left(37-44^{\circ} \mathrm{C}\right), 100-200 \mathrm{~m}$.

This work reports on data obtained from field measurements of radon gas for the period starting from December 1996 up to June 2000 at three radon monitoring stations which were established at Gerakarou, Stivos and Sholari, as well as at the Nea Apollonia spa in the Langadas Basin.

\section{Experimental methods}

The methods of radon measurements in soil gas and in waters of thermal springs that were applied are as follows.
Radon in soil gas was measured first by alpha spectrometry using appropriate Lucas scintillation cells ${ }^{1}$ (George, 1990), in order to define the places of installation of radon stations. The spectrometer was linked to a portable radon monitor, type AB-5 (PYLON), a trace environmental level radon gas detector which detects radon levels as low as $11 \mathrm{~Bq} \mathrm{~m}^{-3}$, and a data acquisition unit (instantaneous radon measurements). The volume of Lucas cells is $270 \mathrm{ml}$ with $\mathrm{Zns}(\mathrm{Ag})$, an active area of $27700 \mathrm{~mm}^{2}$, a counting efficiency

\footnotetext{
$1_{\text {type }} 300$ A (PYLON)
} 

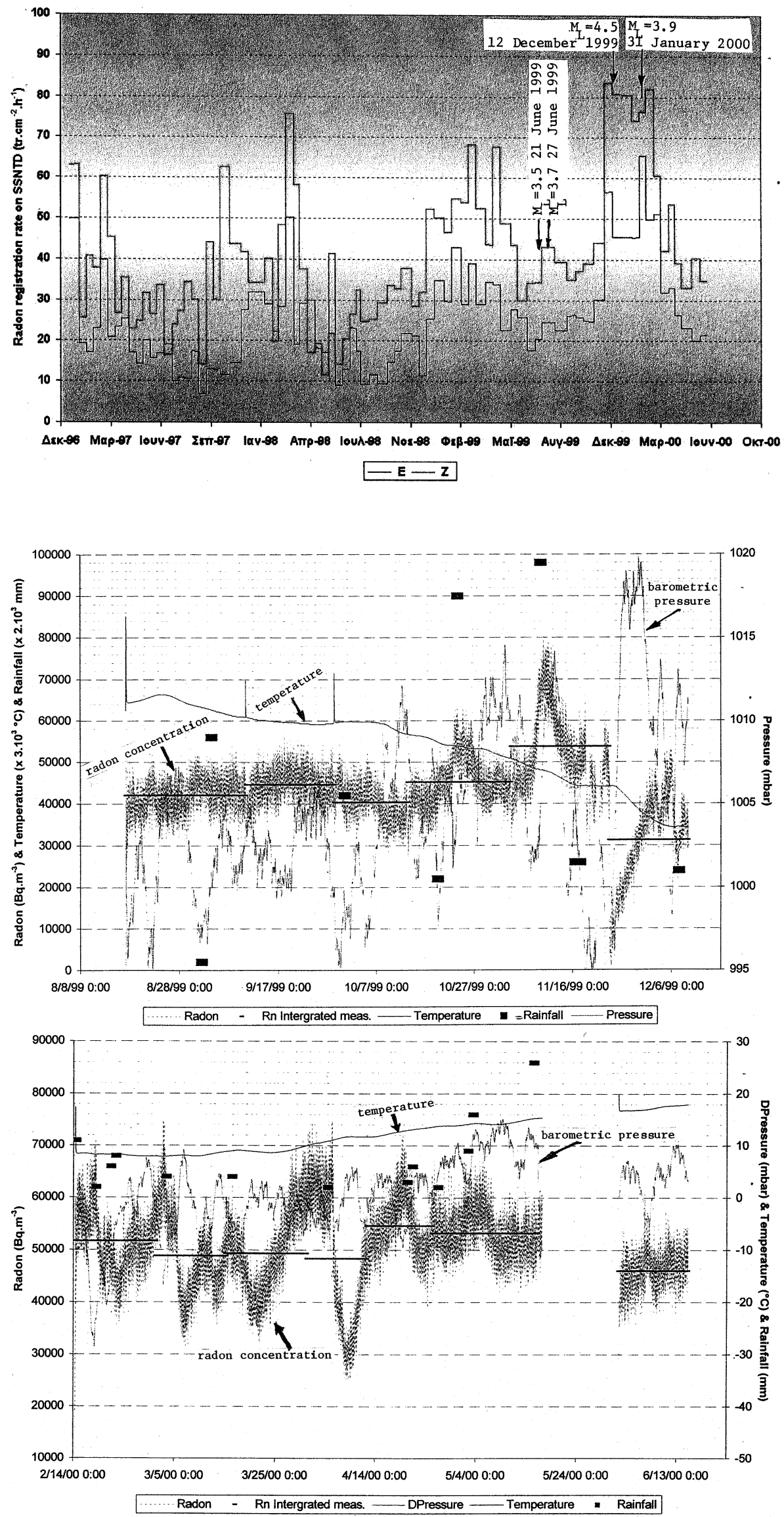

Fig. 2. Radon integrated measurements obtained by SSNTDs at Gerakarou radon station No. 1 in the Langadas Basin.
Fig. 3. (a) Radon concentration in soil gas at Stivos radon station No. 2 during the period of August-December 1999 in correlation with rainfall, soil temperature and pressure. (b) Radon concentration in soil gas at Stivos radon station No. 2 during the period of FebruaryJune 2000 in correlation with rainfall, soil temperature and pressure. 


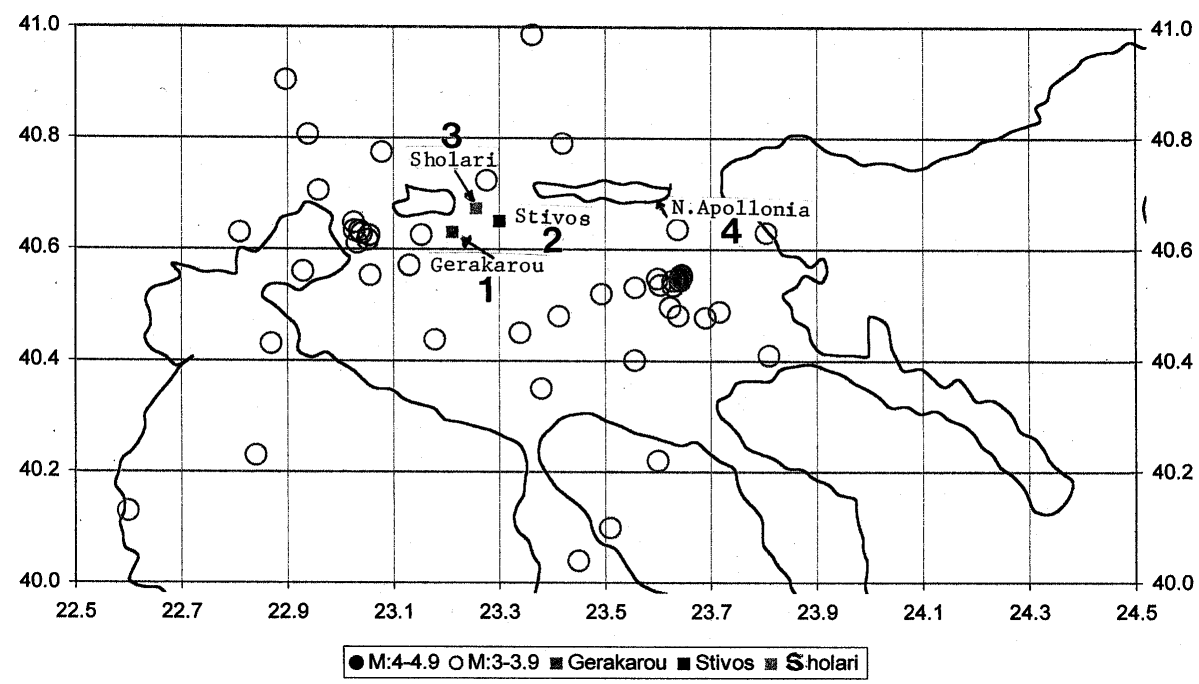

Fig. 4. Seismic events $\left(M_{L}>3\right)$ occurred in the wide region of interest, ROI with epicenter $<50 \mathrm{~km}$ for the period of January 1997-June 2001. of $0.75 \pm 0.02 \mathrm{cpm} \mathrm{dpm}^{-1}$, a sensitivity of $0.037 \mathrm{cpm} \mathrm{Bq}^{-1}$ $\mathrm{m}^{3}$, radon detection levels as low as $11 \mathrm{~Bq} \mathrm{~m}^{-3}$. The soil gas was pulled off at opened holes of $70 \mathrm{~cm}$ depth.

Radon in soil gas was also monitored for long time periods by LR-115 Kodak type II, non-strippable nuclear track-etch detectors (integrated radon measurements) (Alter and Fleischer, 1981) in specially made devices consisting of a plastic tube, $44 \mathrm{~mm}$ inner diameter, $50 \mathrm{~mm}$ outer diameter and $300 \mathrm{~mm}$ in length, with the detectors being on top of the tube, secured appropriately. The plastic tube with radon detector was set inside another plastic tube of $1000 \mathrm{~mm}$ in length with a $70 \mathrm{~mm}$ inner diameter. The empty space between the two plastic tubes was filled with styrofoam material in granule form to thermally isolate the devices. In order to avoid moisture effects on the registration of alpha particles to the detector's surface, a glass fiber type GF/B was placed in front of the plastic detector. The time of exposure was 15 days.

For continuous monitoring of radon gas exhaling from the ground, appropriate silicon diode detectors ${ }^{2}$ (Abbad et al., 1995; Pinault and Baubron, 1996; Trique et al., 1999) were applied in the middle of August 1999, having a background counting below 1 event every $24 \mathrm{~h}$, a useful area of $450 \mathrm{~mm}^{2}$, a depleted depth of $100 \mu \mathrm{m}$ (microns), a sensitivity of 0.02 pulses $\mathrm{h}^{-1} \mathrm{~Bq}^{-1} \mathrm{~m}^{3}$, a resolution with the detector placed in the air $60 \mathrm{keV}$, a radon detection limit of $50 \mathrm{~Bq} \mathrm{~m}^{-3}$ and a saturation volumic activity of $3 \mathrm{MBq} \mathrm{m}^{-3}$. Atmospheric parameters, like temperature $\left({ }^{\circ} \mathrm{C}\right)$, barometric pressure (mbar) and rain precipitation $(\mathrm{mm})$ were recorded simultaneously by the sensors provided by the detector probes. Radon registrations were performed every $15 \mathrm{~min}$.

For continous monitoring of radon gas in waters of thermal springs, appropriate silicon diode detectors ${ }^{3}$ (Pane et al., 1995) were applied having sensitivity 1 count $^{-1}=362 \mathrm{~Bq}$ $\mathrm{m}^{-3}$. A response-function test for this type of detector was performed using a calibrated radon source, type RN-1025-

\footnotetext{
${ }^{2}$ Barasol probes

${ }^{3}$ Clipperton type detectors
}

20, $20 \mathrm{kBq}$ (PYLON). The data storage units were set far away from the radon detectors that were inside the waters to avoid any influence of electric fields to detecting probes. Specially made detector supporters were provided if the waters were too deep. Radon registrations were performed every $15 \mathrm{~min}$.

\section{Results and discussion}

Results of radon integrated measurements by solid-state nuclear track-etch detectors for the period of December 1996 through June 2000 obtained at the Gerakarou radon station No. 1 (Fig. 1a) are illustrated in Fig. 2. The data showed radon registrations higher than 80 tracks $\mathrm{cm}^{-2} \mathrm{~h}^{-1}$ at the Gerakarou radon station No. 1, as well as at the Stivos radon station No. 2, following an $M_{L}=4.5$ earthquake event that occurred on 12 December 1999 and the $M_{L}=3.9$ earthquake event that occurred on 31 January 2000. Earthquake events of $M_{L}=3.5$ (21 June 1999) and $M_{L}=3.7$ (17 June 1999) were not associated with significant radon anomalies (Fig. 2). Radon registrations up to 60 tracks $\mathrm{cm}^{-2} \mathrm{~h}^{-1}$ were recorded in the Sholari radon station No. 3. Similar plots to that of Fig. 2 were obtained for the radon stations No. 2 and No. 3.

Results of radon concentrations in soil gas in the continuous monitoring of radon by Barasol detectors for the period of August 1999 through June 2000 obtained at the Stivos radon station No. 2 are illustrated in Figs. 3a and 3b. In the period of August 1999 through December 1999, there seems to be a background of $40 \mathrm{kBq} \mathrm{m}^{-3}$ for radon in soil gas (Fig. 3a), while in the period of February 2000 through June 2000 , the background rose to about $50 \mathrm{kBq} \mathrm{m}^{-3}$ for radon in soil gas (Fig. 3b), possibly indicating higher seismic activity to be followed in the next period. Beside this, only one earthquake event with a magnitude higher than 4.0 occurred at the region of interest; ROI in the period of measurements, that of $M_{L}=4.5$, occurred on 12 December 1999. Unfortunately, 
at that period (December 1999 through January 2000, a twomonth period), the Barasol detectors were not in the radon stations in the field for technical reasons (updating of software by the manufacturer). So, we missed two months of data which could show radon anomalies at the radon spectra. Better results are expected for the cases of large earthquake events with magnitudes higher than 5.0 (Papastefanou et al., 1989), which, however, did not occur in the period of measurements. Similar plots to those of Figs. 3a and $3 b$ were obtained for the Gerakarou radon station No. 1 and the Sholari radon station No. 3. The seismic events that occurred in the wide region of interest are illustrated in Fig. 4. The seismic data have been provided by the Laboratory of Geophysics, Aristotle University of Thessaloniki, Greece. The variation of radon concentration in soil gas might be slightly affected by changes in barometric pressure, moisture (precipitation) and temperature (Mogro-Campero et al., 1980).

Radon measurements performed in drillings ranging from 25 to $50 \mathrm{~m}$ in depth, at Nea Apollonia spa, No. 4 in the Langadas Basin (Fig. 1b) showed that radon concentrations varied from 4365 to $54415 \mathrm{~Bq} \mathrm{~m}^{-3}$ at depth $25 \mathrm{~m}$ and as high as $53100 \mathrm{~Bq} \mathrm{~m}^{-3}$ at depth $50 \mathrm{~m}$, associated with the seismic active fault zones (Haukksson, 1981) like that in the Langadas Basin.

\section{Appendix A Explanations of geological map of Langadas Basin (Fig. 1a)}

SEDIMENTARY ROCKS QUATERNARY

\section{HOLOCENE}

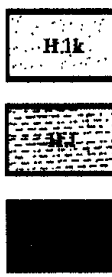

Lacustrine sodiments: Sandy clay, silt and finegrained sand rich in mica

Valley Deposits: Sandy clay

Deposits in river and torrent beds: Sandy clay, sand and grits

PLEISTOCENE

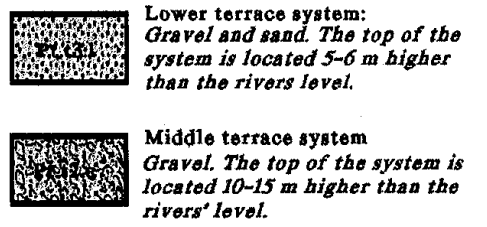

OUATERNARY UNDIVIDED

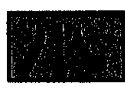

Fang:

of different age

TERTIARY

UPPER MIOCENE - LOWER PLIOCENE

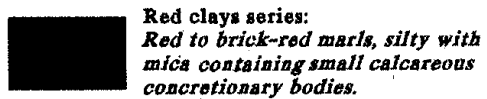

mica containing small calcareous

concretionary badies.

\section{METASEDIMENTARY ROCKS}

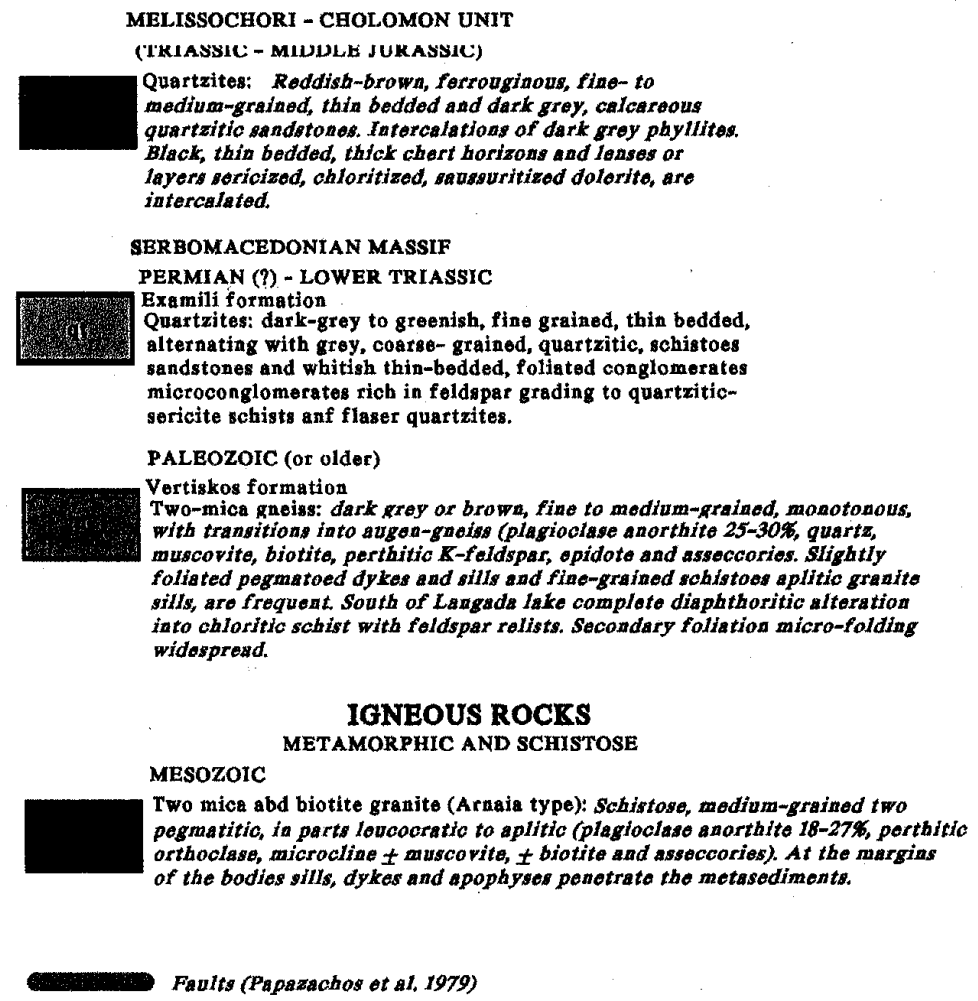

Acknowledgements. This work was sponsored by the Commission of the European Communities under the contract No. IC15-CT960214 of the EMANE project of the INCO-Copernicus Programme.

\section{References}

Abbad, S., Robe, M. C., Bernat, M., and Labed, V.: Influence of Meteorological and Geological parameter variables on the concentration of radon in soil gases: Application to seismic forecasting in the Province-Alpes-Côte d'Azur region, Environ. Geochim. Health, 16S, 35-48, 1995.
Alter, H. W. and Fleischer, R. L.: Passive integrating radon monitor for environmental monitoring, Health Phys., 40, 693-702, 1981.

George, A. C.: An overview of instrumentation for measuring environmental radon and radon progeny, Rep. T-NS/37/2/1/38220, IEEE Trans. Nucl. Sci., 37, 892-901, 1990.

Hauksson, E.: Radon content of ground water as an earthquake precursor: Evaluation of worldwide data and physical basis, J. Geophys. Res., 86, 9397-9410, 1981.

King C. Y.: Temporal variations in radon emanation along active faults, EOS Trans. AGU, 58, 434, 1977.

King C. Y.: Anomalous changes in radon emanation and ground water quality, EOS Trans. AGU, 59, 1196, 1978.

King C. Y.: Episodic radon changes in subsurface soil gas along ac- 
tive faults and possible relation to earthquakes, J. Geophys. Res., 85, 3065-3078, 1980.

Mogro-Campero A., Fleischer, R. L., and Likes R. S.: Changes in subsurface radon concentration associated with earthquakes, J. Geophys. Res., 85, 3053-3057, 1980.

Pane, M. B., Seidel, J. L., Monnin, M., and Morin, J. P.: Radon as a tracer of fluid motion in fractural aquifers, Environ. Geochim. Health, 16S, 325-334, 1995.

Papastefanou, C., Manolopoulou, M., Savvides, E., and Charalambous, S.: Radon monitoring at the Stivos Fault following the $\mathrm{M}_{L}$ $=6.5$ earthquake which occurred at Thessaloniki, Greece on 20 June 1978, Nucl. Geophys, 3, 49-56, 1989.

Pinault, J.-L. and Baubron, J.-C.: Signal processing of soil gas radon, atmospheric pressure, moisture and soil temperature data: A new approach for radon concentration modeling, J. Geophys. Res., 101(B2), 3157-3171, 1996.

Scholz C. H., Sykes, L. R., and Aggarwal Y. P.: Earthquake prediction: A physical basis, Science, 181, 803-810, 1973.

Skordilis, E. M.: Microseismic study of the Servomacedonian Zone and the surrounding area, $\mathrm{PhD}$ thesis, Aristotle University of Thessaloniki, Thessaloniki, Greece, 1985.

Trique, M., Richon, P., Perrier, F., Avouac, J. P., and Sabroux, J. C.: Radon emanation and electric potential variations associated with transient deformation near reservoir lakes, Nature, 399, 137-141, 1999. 